\title{
Relationship of Seed Traits on Initial Progeny Growth Performance and Divergence Studies in Madhuca latifolia Macb. for Further Use in Tree Improvement
}

\author{
B.N. Divakara ${ }^{1 *}$ \\ ${ }^{1}$ Institute of Wood Science and Technology, Mellashwaram, Bangalore, India
}

Date Received: 18-01-2013 Date Accepted: 03-07-2014

\begin{abstract}
Evaluation of 23 genotypes of Madhuca latifolia was carried out based on relationship of seed traits with initial progeny growth performance and divergence studies as a scope for further breeding programme. Variability studies revealed that, more than 12 accessions recorded above average for 100-

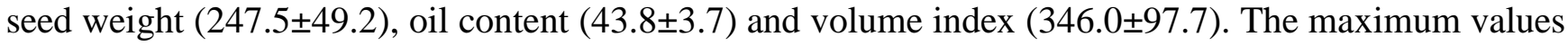
observed in studied CPTs were as follows: seed length $(39.1 \mathrm{~mm})$ in CPT-15 genotype, seed breadth (19.2 mm) in CPT-8 and CPT-9, aspect ratio (2.2) in CPT-6 and CPT-15, 2D surface area (501.4 and $\left.491.6 \mathrm{~mm}^{2}\right)$ in CPT-9 and CPT-3 respectively. CPT-16 recorded maximum for 100 seed weight $(282.4$ g) and oil content (51.2\%). However, maximum volume index was recorded by CPT-3 $\left(578.3 \mathrm{~cm}^{3}\right)$ followed by CPT-16 $\left(496.0 \mathrm{~cm}^{3}\right)$. The phenotypic and genotypic coefficients of variations are close to each other for all traits, except volume index that exhibited striking difference between PCV (40.0\%) and GCV (19.9\%) indicating that for most traits genetic control was quite high. Trait oil content and 100 seed weight expressed high heritability $(93.5 \%, 93.0 \%)$ accompanied with moderate genetic advance $(17.2 \%, 15.6 \%)$, indicating that, heritability is due to additive gene effects and selection may be effective. At genotypic level 100 seed weight registered positive significant correlation with plant height (0.73), oil content with volume index (0.71). Hence seeds with large breadth, high seed weight and oil content may be selected for producing better progenies. Since traits viz. 100 seed weight and oil content are under strong genetic control, improvement in these characters can bring improvement in volume index. On the basis of the divergence, the 23 genotypes studied were grouped into 5 clusters, indicating wide diversity. The clustering pattern shows that geographical diversity is not necessarily related to genetic diversity. The genotypes in cluster IV and V were most heterogeneous and can be best used for within group hybridization. Cluster means indicated crosses involving under cluster II and $\mathrm{V}$ and cluster II and I may result in substantial segregates and further selection for overall improvement of species.
\end{abstract}

Keywords: Madhuca latifolia, heritability, genetic advance, genetic divergence, correlation

\section{Introduction}

Madhuca latifolia Macb. (Syn M. indica J.F. Gmel; Bassia latifolia Roxb.) of family Sapotaceae, vernacularly and commonly known as mahua and Indian Butter Tree is a large, branched deciduous tree indigenous to the Indian subcontinent. It is predominantly grown in dry tropical and

* Correspondence: bndsira@gmail.com

Tel: +918022190198

ISSN 2235-9370 Print/ISSN 2235-9362 Online (C) University of Sri Jayewardenepura 
sub-tropical regions of Indo-Pakistan subcontinent. The species is scattered in deciduous forests and dry sal plain forests. Plant grows upto $18 \mathrm{~m}$ height with short bole, grey to black bark and round crown. It is extensively cultivated in villages of northern India and Deccan peninsula for sweet fleshy corolla and ripe fruits which is used as a major source of industrial alcohol as well as country liquor, portable spirit and vinegar. Seeds contain a valuable fatty oil ranging from $38 \%$ to $57 \%$, known as mahua oil or butter of romance. Mahua oil is used as edible oil, manufacture of margarine, soap, glycerin, lubricating grease and medicine. Seed cake is used as biofertilisers, organic manure, biocide and fish meal. Its leaves used for fodder and green manure while bark gives tannin (CSIR, 1998). Due to presence of similar properties to that of diesel, Mahua oil has gained the importance as bio-diesel and is emerging as a viable alternative to fossil fuel. Importantly, the successful adoption of bio-fuels is reliant on the supply of feedstock from non-food crops with the capacity to grow on marginal land not destined to be used for the cultivation of food crops (Hill et al., 2006). Meeting both of these criteria and thus, can form the basis of a highly promising, profitable, and self-sustaining platform for smallscale entrepreneurship and self-employment in rural areas, ensuring optimum utilisation of wasteland resources and unemployed manpower. Although $M$. latifolia is well known as oil yielding tree having wide adaptability and plethora of uses, little attempt has been directed to improve it as a crop plant because of long gestation period and slow growing nature. The wide gap in potential and actual yield is due to the use of locally available wild material. No systematic breeding program for breeding superior high yielding genotypes has been initiated. M. latifolia being open pollinated crop (Anemophillic), provide ample scope for genetic improvement through selection of superior trees with genetic variation in seed morphology and oil content along with initial progeny performance which later can be of great potential and may have greater impact than the conventional breeding. Hence, the challenging task, as of today is to screen the naturally available $M$. latifolia genetic resources to select the best planting material with high oil content for higher productivity. The available information in literature does not provide a complete understanding of geographical variation and its influence on improvement of seed quality and quantity. The information on the genetic structure and diversity relationship of candidate plus trees provide a basis for planning and conducting future collections and efficient utilization of genetic resources to realize the potentiality for maximizing seed and oil yield. Keeping precarious scenario in view, an effort was made to investigate the relationship of seed traits with initial progeny growth performance for early selection and divergence studies to understand the diversity among 23 accessions for assessment and creation of diverse lines in $M$. latifolia for further use in tree improvement.

\section{Material and Methods}

An extensive wild germplasm exploration survey was conducted to identify the high yielding Candidate Plus Trees (CPTs) of $M$. latifolia at fruiting stage from different predominant naturalized locations in Jharkhand, India (Table 1, Figure 1). The selection was made on phenotypic assessment of characters of economic importance viz yield potential, crown spread, total height, girth at breast height, age of the tree, free from pest and diseases, seed size and seed weight. A total of 23 CPTs (morphologically superior trees) covering a latitude and longitudinal range between $22^{0} 00^{\prime} \mathrm{N}$ to $24^{0} 50^{\prime}$ $\mathrm{N}$ and $83^{\circ} 30^{\prime} \mathrm{E}$ to $87^{\circ} 00^{\prime} \mathrm{E}$, respectively, were selected (Table 1). From each CPTs, $2 \mathrm{Kg}$ of mature capsules were collected during June-July, 2005. Quantitative characterization was carried out (6 seed and 3 progeny characters) at Forest Research Centre, Institute of Forest Productivity Mandar, Ranchi District during 2005-07. 


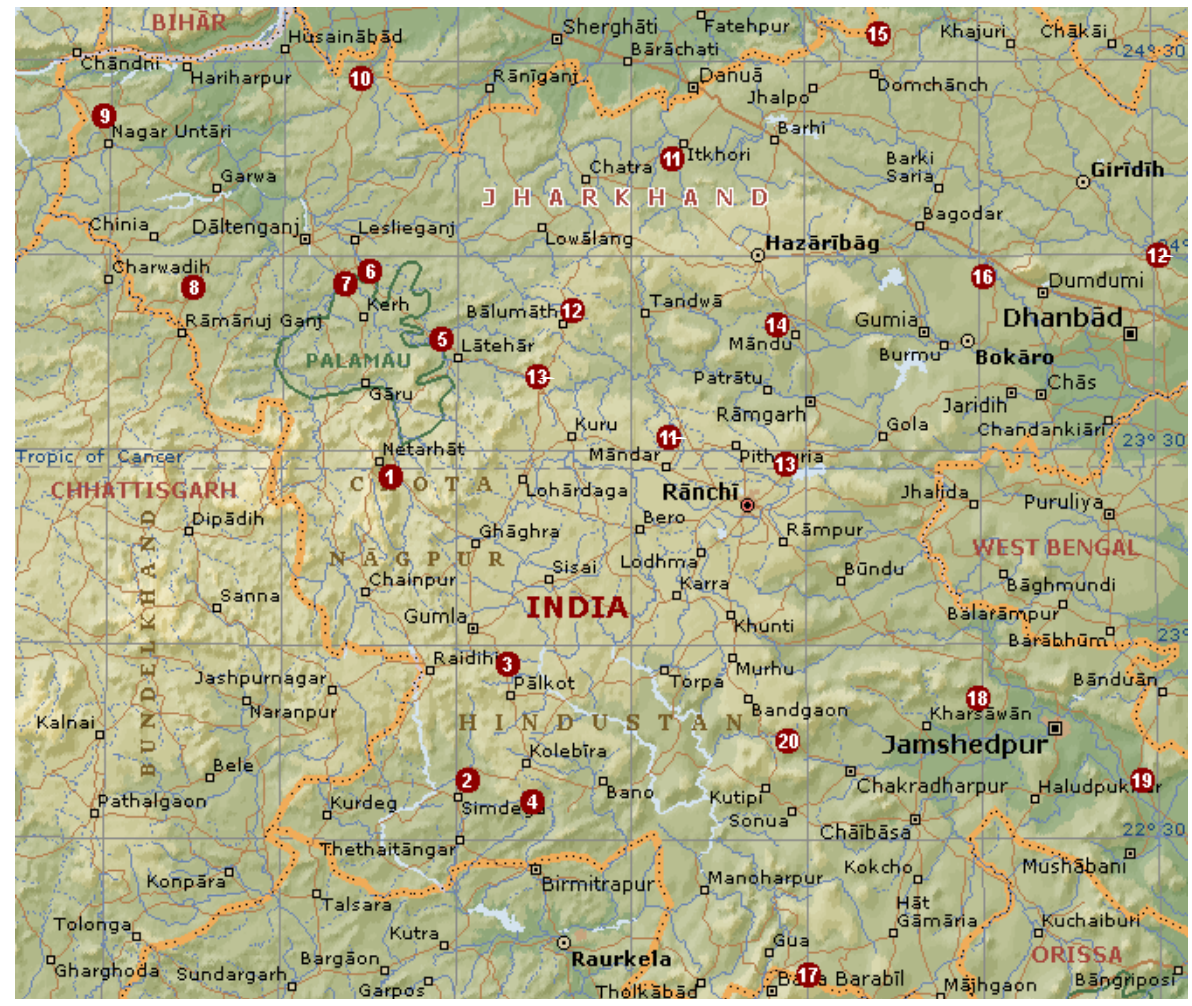

Figure 1: Distribution of Madhuca latifolia Candidate Plus Trees in Jharkhand, India mapped using Microsoft Encarta 2005

Note: Details of number representation is in table 1.

\subsection{Site characteristics}

The study area under Forest Research Centre (latitude: $23^{\circ} 27^{\prime} 40^{\prime \prime} \mathrm{N}$, longitude: $85^{\circ} 05^{\prime} 56^{\prime \prime} \mathrm{E}$, altitude 2,320 ft msl approx.) has a semi-arid type of climate. Mean annual rainfall is $1231.6 \mathrm{~mm}$ with mean number of rainy days 73.6. Annual minimum and maximum temperature is recorded as $17.7^{\circ} \mathrm{C}$ and $30.2^{0} \mathrm{C}$ respectively with lowest temperature in January and highest temperature in May. Soils of the study area is characterized by $\mathrm{pH}(5.7)$, EC (35), organic carbon (0.33\%), nitrogen (105 ppm), phosphorus (11 ppm) and potassium (74 ppm).

\subsection{Seed characters}

Samples of 300 seeds were randomly collected from each CPT to make three replicates with 100 seeds in each. Measurement of morphological traits viz. seed length, seed breadth, aspect ratio and 2D surface area, was carried out using Image analyzer (Leica Quantimet called QWin 500). Seeds were spread on a glass platform of macro-viewer for each replication and images were captured using charge coupled device (CCD) camera. These images were analysed using Quantimet 500+ or Qwin software. The Qwin identifies the object based on given specification for seed colour and calibrates captured images to actual scale. Different two dimensional (2D) measurements of the detected images were measured (Table 2). 
Table 1: Locational details of Madhuca latifolia Candidate Plus Trees (CPTs) selected in Jharkhand, India.

\begin{tabular}{|c|c|c|c|c|c|c|c|c|c|c|}
\hline CPTs & District & Location/Village & Latitude & Longitude & $\begin{array}{l}\text { Alt, } \\
\text { m }\end{array}$ & $\begin{array}{l}\text { Age, } \\
\mathrm{yr}\end{array}$ & $\begin{array}{l}\mathrm{H}, \\
\mathrm{m}\end{array}$ & $\begin{array}{l}\mathrm{D}, \\
\mathrm{cm}\end{array}$ & $\begin{array}{l}\text { Seed } \\
\text { yield, } \\
\text { kg yr }^{-1}\end{array}$ & $\begin{array}{l}\text { Crown } \\
\text { area } \\
\left(\mathrm{m}^{2}\right)\end{array}$ \\
\hline CPT-1 & Lohardaga & Chingri Nawatoli & $23^{\circ} 26^{\prime} 19 \mathrm{~N}$ & $84^{\circ} 18^{\prime} 25 \mathrm{E}$ & 590 & 95 & 10.0 & 80 & 300 & 294.19 \\
\hline CPT-2 & Simdega & Pharsabera Kusumtoli & $22^{\circ} 39^{\prime} 17 \mathrm{~N}$ & $84^{\circ} 31^{\prime} 56 \mathrm{E}$ & 410 & 65 & 13.6 & 90 & 100 & 191.21 \\
\hline CPT-3 & Gumla & Samra Velluwa toil & $23^{\circ} 03^{\prime} 03 \mathrm{~N}$ & $84^{\circ} 52^{\prime} 28 \mathrm{E}$ & 520 & 80 & 15.3 & 53 & 120 & 123.75 \\
\hline CPT-4 & Simdega & Piosokra & $22^{\circ} 36^{\prime} 06 \mathrm{~N}$ & $84^{\circ} 43^{\prime} 01 \mathrm{E}$ & 370 & 80 & 17.5 & 119 & 180 & 331.81 \\
\hline CPT-5 & Latehar & Hotwag & $23^{\circ} 47^{\prime} 28 \mathrm{~N}$ & $84^{\circ} 27^{\prime} 08 \mathrm{E}$ & 340 & 70 & 15.3 & 70 & 120 & 247.55 \\
\hline СРT-6 & Daltonganj & Sarja Polpol & $23^{\circ} 54^{\prime} 17 \mathrm{~N}$ & $84^{\circ} 31^{\prime} 21 \mathrm{E}$ & 290 & 45 & 13.8 & 70 & 70 & 166.34 \\
\hline СРT-7 & Daltonganj & Akhra & $23^{\circ} 55^{\prime} 59 \mathrm{~N}$ & $84^{\circ} 10^{\prime} 23 \mathrm{E}$ & 250 & 100 & 14.4 & 110 & 200 & 481.30 \\
\hline СРТ-8 & Garhwa & Singakala & $23^{\circ} 55^{\prime} 18 \mathrm{~N}$ & $83^{\circ} 44^{\prime} 15 \mathrm{E}$ & 385 & 100 & 13.6 & 110 & 200 & 452.57 \\
\hline СРТ-9 & Garhwa & Garbandh & $24^{\circ} 21^{\prime} 24 \mathrm{~N}$ & $83^{\circ} 28^{\prime} 39 \mathrm{E}$ & 510 & 60 & 10.3 & 85 & 150 & 166.34 \\
\hline CPT-10 & Daltonganj & Simarbar batawa & $24^{\circ} 27^{\prime} 39 \mathrm{~N}$ & $84^{\circ} 13^{\prime} 04 \mathrm{E}$ & 215 & 70 & 12.0 & 74 & 100 & 247.55 \\
\hline CPT-11 & Chatra & Pitiz & $24^{\circ} 15^{\prime} 19 \mathrm{~N}$ & $85^{\circ} 06^{\prime} 50 \mathrm{E}$ & 375 & 40 & 10.3 & 55 & 30 & 133.81 \\
\hline CPT-12 & Latehar & Nachna & $23^{\circ} 51^{\prime} 54 \mathrm{~N}$ & $84^{\circ} 49^{\prime} 44 \mathrm{E}$ & 540 & 120 & 9.8 & 103 & 200 & 216.51 \\
\hline СРТ-13 & Ranchi & Piska Mahua Toli & $23^{\circ} 28^{\prime} 03 \mathrm{~N}$ & $85^{\circ} 26^{\prime} 24 \mathrm{E}$ & 610 & 50 & 14.0 & 60 & 150 & 203.67 \\
\hline СРТ-14 & Hazaribag & Ahoanhe moraha & $23^{\circ} 49^{\prime} 37 \mathrm{~N}$ & $85^{\circ} 24^{\prime} 55 \mathrm{E}$ & 510 & 40 & 10.2 & 54 & 70 & 166.34 \\
\hline CPT-15 & Koderma & Banpok & $24^{\circ} 34^{\prime} 36 \mathrm{~N}$ & $85^{\circ} 42^{\prime} 47 \mathrm{E}$ & 390 & 80 & 10.2 & 70 & 100 & 125.73 \\
\hline CPT-16 & Giridih & Madhgopali & $23^{\circ} 56^{\prime} 56 \mathrm{~N}$ & $86^{\circ} 00^{\prime} 44 \mathrm{E}$ & 340 & 70 & 11.0 & 78 & 100 & 212.62 \\
\hline CPT-17 & Chaibasa & Khas Jamda & $22^{\circ} 09^{\prime} 08 \mathrm{~N}$ & $85^{\circ} 2954 \mathrm{E}$ & 550 & 70 & 12.8 & 80 & 100 & 229.75 \\
\hline CPT-18 & Saraikela & Palobera & $22^{\circ} 15^{\prime} 52 \mathrm{~N}$ & $85^{\circ} 59^{\prime} 14 \mathrm{E}$ & 300 & 45 & 15.4 & 65 & 60 & 243.38 \\
\hline СРТ-19 & Jamshedpur & Golkatta & $22^{\circ} 39^{\prime} 02 \mathrm{~N}$ & $86^{\circ} 27^{\prime} 09 \mathrm{E}$ & 190 & 50 & 12.7 & 52 & 70 & 128.73 \\
\hline CPT-20 & Chaibasa & Junko & $22^{\circ} 45^{\prime} 19 \mathrm{~N}$ & $85^{\circ} 26^{\prime} 25 \mathrm{E}$ & 450 & 50 & 17.7 & 70 & 100 & 308.03 \\
\hline СРТ-21 & Ranchi & PaniMahua Chamma & $23^{\circ} 32^{\prime} 27 \mathrm{~N}$ & $85^{\circ} 06^{\prime} 17 \mathrm{E}$ & 650 & 50 & 14.0 & 60 & 150 & 203.67 \\
\hline CPT-22 & Dhanbad & Kokra & $23^{\circ} 59^{\prime} 50 \mathrm{~N}$ & $86^{\circ} 30^{\prime} 45 \mathrm{E}$ & 240 & 90 & 14.3 & 97 & 100 & 274.76 \\
\hline CPT-23 & Latehar & Chandwa & $23^{\circ} 41^{\prime} 42 \mathrm{~N}$ & $84^{\circ} 43^{\prime} 36 \mathrm{E}$ & 520 & 80 & 13.8 & 106 & 120 & 335.05 \\
\hline
\end{tabular}

Table 2: Methodology for measuring seed and progeny traits of Madhuca latifolia.

\begin{tabular}{lll}
\hline S1. No. & Traits & Method \\
\hline 1 & Seed length $(\mathrm{mm})$ & Length of the seed at longest side. \\
2 & Seed breadth $(\mathrm{mm})$ & Length of the seed at shortest side. \\
3 & Aspect ratio & Length was divided by breadth. \\
7 & 2D surface area $\left(\mathrm{mm}^{2}\right)$ & 2D surface area of the seed in the direction of measurement. \\
5 & $100-$ seed weight $(\mathrm{g})$ & $\begin{array}{l}\text { Weight of } 100 \text { seeds weighed on electronic balance was measured in } \\
\text { grams. }\end{array}$ \\
5 & Oil content $(\%)$ & Estimated using soxhlet apparatus following the procedure of \\
& Sadasivam and Manickam (1992). \\
7 & Plant height $(\mathrm{cm})$ & Length of the plant from ground level to tip. \\
3 & Collar diameter $\left(\mathrm{cm}^{3}\right)$ & Stem diameter near the ground level. \\
7 & Volume index $\left(\mathrm{cm}^{3}\right)$ & Collar diameter $(\mathrm{cm})]^{2} \times$ Plant height $\left.(\mathrm{cm})\right]$ (Manavalan 1990). \\
\hline
\end{tabular}

\subsection{The progenies}

Seeds of all the CPTs were pre-treated by soaking in cold water for 24 hours. Pretreated seeds of each CPTs were directly sown in polythene bags of dimension $30 \times 12 \times 10 \mathrm{~cm}$ filled with potting mixture of soil, sand and farmyard manure (2:1:1) in three replicates of 100 seeds each, during July 2005. Samples of six one-year-old seedlings were planted with spacing of $3.5 \times 3.5 \mathrm{~m}$ in the field with (pit size $45 \times 45 \times 45 \mathrm{~cm}$ ) for field evaluation at Forest Research Centre in July 2006. Randomised Complete Block Design (RCBD) with three replicates was used. After 30 months of sowing (Juvenile stage), observations were recorded on the trial for plant height $(\mathrm{m})$ and collar diameter $(\mathrm{cm})$ were measured at bimonthly intervals over a period of 18 months. The data recorded at 18 months after sowing (MAS) alone was considered for variability, correlation and diversity studies. The results are given in the (Table 3). 


\subsection{Data analysis}

The seed parameters and progeny measurements were analysed using Analysis of variance (ANOVA) and Duncan Multiple Range Test (DMRT) to understand the significance of differences between the seeds and progenies of CPTs (Gomez and Gomez, 1984). The phenotypic variation for each trait was partitioned into components based on genetic (hereditary) and non-genetic (environmental) factors and estimated using the following formula (Johanson et al., 1955):

$$
\mathrm{V}_{\mathrm{p}}=\mathrm{MSG} / \mathrm{r} ; \mathrm{V}_{\mathrm{g}}=(\mathrm{MSG}-\mathrm{MSE}) / \mathrm{r} ; \mathrm{V}_{\mathrm{e}}=\mathrm{MSE}
$$

MSG, MSE and $r$ are the mean squares of CPTs, mean squares of error and number of replications, respectively.

The phenotypic variance $\left(\mathrm{V}_{\mathrm{p}}\right)$ is the total variance among phenotypes when grown over the range of environments of interest, the genotypic variance $\left(\mathrm{V}_{\mathrm{g}}\right)$ is the part of the phenotypic variance that can be attributed to genotypic differences among the phenotypes, and the error variance $\left(\mathrm{V}_{\mathrm{e}}\right)$ is part of the phenotypic variance due to environmental effects. To compare the variation among traits, phenotypic (PCV) and genotypic (GCV) coefficients of variation were computed according to the method suggested by Burton, (1952)

$$
\mathrm{PCV}=\left(\sqrt{ } \mathrm{V}_{\mathrm{p}} / \mathrm{X}\right) \times 100 ; \mathrm{GCV}=\left(\sqrt{\mathrm{V}_{\mathrm{g}}} / \mathrm{X}\right) \times 100
$$

$\mathrm{V}_{\mathrm{p}}, \mathrm{V}_{\mathrm{g}}$ and $\mathrm{X}$ are the phenotypic variance, genotypic variance and grand mean for each pod and seed-related trait, respectively.

Broad sense heritability $\left(h^{2} \mathrm{~B}\right)$ was calculated according to Allard (1999) as the ratio of the genotypic variance $\left(\mathrm{V}_{\mathrm{g}}\right)$ to the phenotypic variance $\left(\mathrm{V}_{\mathrm{p}}\right)$. Genetic advance $(\mathrm{GA})$ expected and GA as per cent of the mean assuming selection of the superior 5\% of the genotypes were estimated in accordance with Johanson et al., (1955), as in the following equation.

$$
\mathrm{GA}=\mathrm{K} \cdot \mathrm{h}^{2} \mathrm{~B} \cdot \sqrt{ } \mathrm{Vp} ; \mathrm{GA}(\text { as } \% \text { of the mean })=(\mathrm{GA} / \mathrm{X}) \times 100
$$

$\mathrm{K}$ is the selection differential (2.06 for selecting $5 \%$ of the genotypes).

Phenotypic $\left(\mathrm{r}_{\mathrm{p}}\right)$ and genotypic $\left(\mathrm{r}_{\mathrm{g}}\right)$ correlations were further computed to examine inter-character relationships among seed and seedling traits following Goulden (1952) as given below.

$$
\begin{aligned}
& \mathrm{r}_{\mathrm{p}}=\operatorname{Cov}_{\mathrm{p}}\left(\mathrm{x}_{1}, \mathrm{x}_{2}\right) /\left[\mathrm{V}_{\mathrm{p}}\left(\mathrm{x}_{1}\right) \cdot \mathrm{V}_{\mathrm{p}}\left(\mathrm{x}_{2}\right)\right]^{1 / 2} \\
& \mathrm{r}_{\mathrm{g}}=\operatorname{Cov}_{\mathrm{g}}\left(\mathrm{x}_{1}, \mathrm{x}_{2}\right) /\left[\mathrm{V}_{\mathrm{g}}\left(\mathrm{x}_{1}\right) \cdot \mathrm{V}_{\mathrm{g}}\left(\mathrm{x}_{2}\right)\right]^{1 / 2}
\end{aligned}
$$

$\operatorname{Cov}_{\mathrm{p}}$ and $\operatorname{Cov}_{\mathrm{g}}$ are phenotypic and genotypic covariances for any two traits $\mathrm{x}_{1}$ and $\mathrm{x}_{2}$, respectively, and $\mathrm{Vp}$ and $\mathrm{Vg}$ are the respective phenotypic and genotypic variances for those traits. The genetic diversity was estimated using the Mahalanobis D2 statistics (Mahalanobis, 1936). Tracing $\mathrm{D}^{2}$ as a generalised distance, the criterion used by Tocher as described by Rao (1952) was applied for determining the clustration group. Average intra and inter cluster distances were determined using GENRES version 3.11, 1994 Pascal Intl. Software and suggested by Singh and Chaudhary (1977). 


\section{Results}

Mean parent seed and progeny growth characters of twenty-three tested CPTs of $M$. latifolia are presented in Table 3. There is a significant difference among all seed and progenies traits. Variability studies revealed that, more than twelve accessions recorded are above average for 100-seed weight

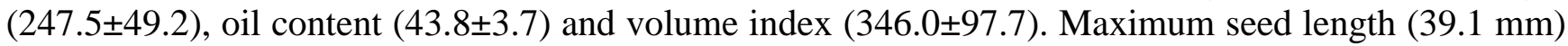
was observed in CPT-15 genotype, while seed breadth $(19.2 \mathrm{~mm})$ was maximum in CPT-8 and CPT-9, Aspect ratio (2.2) was highest in CPT-6 and CPT-15. 2D surface area (501.4 and $\left.491.6 \mathrm{~mm}^{2}\right)$ was highest in CPT-9 and CPT-3 respectively. CPT-16 recorded the maximum for 100 seed weight $(282.4$ g) and oil content $(51.2 \%)$. However, maximum volume index was recorded in CPT-3 $\left(578.3 \mathrm{~cm}^{3}\right)$ followed by CPT-16 $\left(496.0 \mathrm{~cm}^{3}\right)$. Lowest seed weight (for $100 \mathrm{seed}$ ), oil content and volume index was expressed in genotypes CPT-4 (216.0 g) lowest oil content in CPT-21 (37.7 \%) and lowest volume index in CPT-12 $\left(176.5 \mathrm{~cm}^{3}\right)$ respectively. Genotype CPT-19 and CPT-23 recorder lowest for seed length $(26.8 \mathrm{~mm})$, aspect ratio $(1.6)$ and seed breadth $(15.5 \mathrm{~mm}), 2 \mathrm{D}$ surface area $\left(321.5 \mathrm{~mm}^{2}\right)$.

Table 3: Mean performance of selected genotypes of Madhuca latifolia for seed and progeny growth traits.

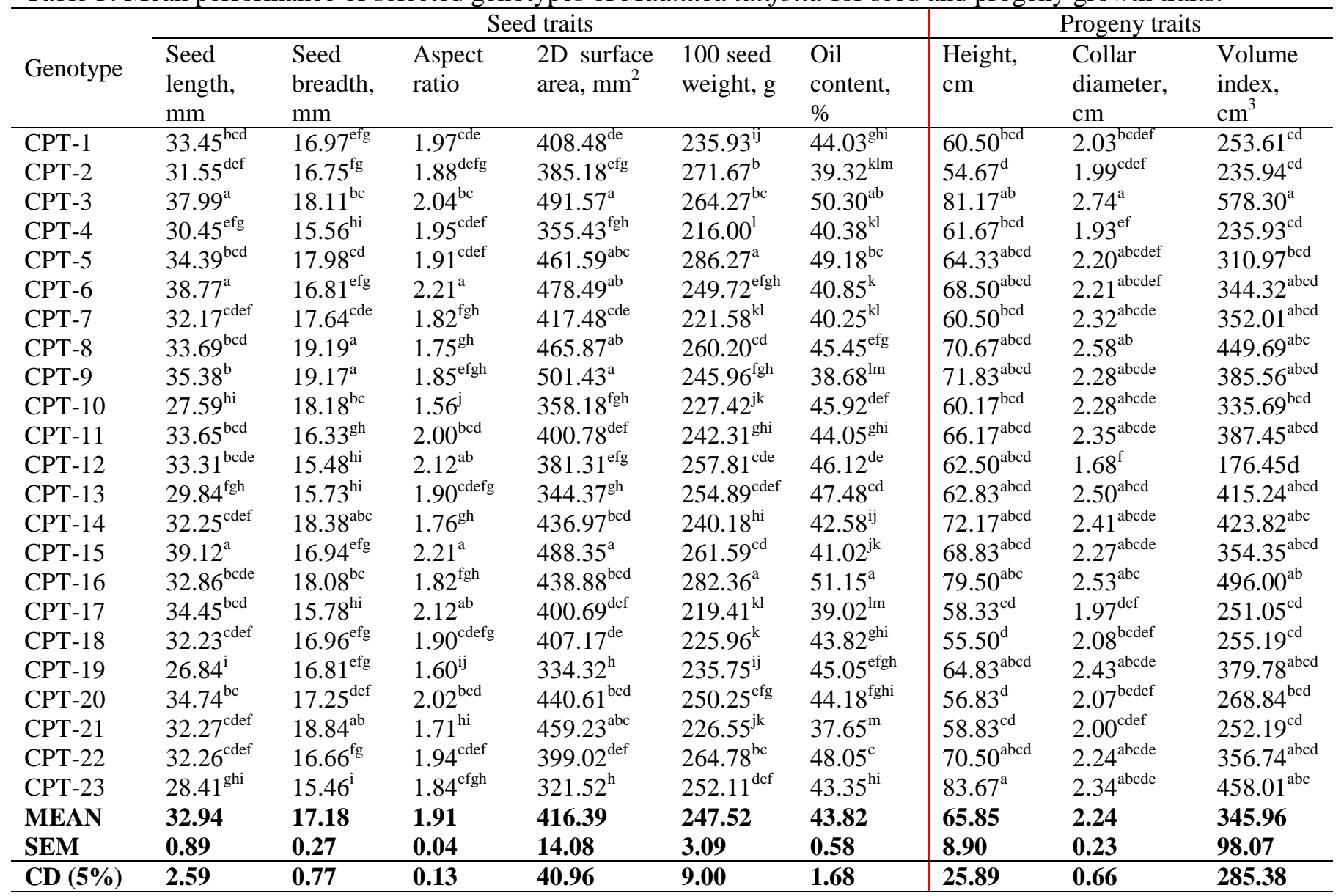

Trait means not followed by the same superscript letter are significantly different at $\mathrm{p}=0.05$.

The phenotypic and genotypic coefficients of variations are close to each other for all traits, except for volume index that exhibited striking difference between PCV (40.0\%) and GCV (19.9\%) indicating that for most traits, genetic control was quite high (Table 4). All the seed traits showed high heritability while progeny growth characters showed low to moderate heritability. Trait oil content and 100 seed weight expressed high heritability $(93.5 \%, 93.0 \%)$ accompanied with moderate genetic 
advance $(17.5 \%, 15.6 \%)$ indicating that, heritability is due to additive gene effects and thus selection may be effective. Trait volume index expressed moderate heritability (24.7\%) accompanied with high genetic advance (20.4\%). The low heritability is being exhibited due to high environment effects, since trait has high genetic advance, selection will be effective. Similar trend was observed in Casuarina equisitifolia relationship of cone and seed traits on progeny growth performance (Mahadevan et al. 1999).

Table 4: Genetic estimates of parent seed and progeny growth traits.

\begin{tabular}{|c|c|c|c|c|c|c|}
\hline \multirow[t]{2}{*}{ Seed traits } & \multicolumn{2}{|l|}{ Variance } & \multicolumn{2}{|c|}{ Coefficient of variation (\%) } & \multirow{2}{*}{$\begin{array}{l}\text { Heritability } \\
(\%)\end{array}$} & \multirow{2}{*}{$\begin{array}{l}\text { GA }(\%) \text { of } \\
\text { mean }\end{array}$} \\
\hline & Genotypic & Phenotypic & Genotypic & Phenotypic & & \\
\hline Seed length & 9.17 & 11.54 & 9.19 & 10.31 & 79.5 & 16.89 \\
\hline Seed breadth & 1.29 & 1.50 & 6.61 & 7.13 & 85.9 & 12.61 \\
\hline Aspect ratio & 0.03 & 0.03 & 8.70 & 9.58 & 82.4 & 16.26 \\
\hline 2D surface area & 2571.64 & 3165.93 & 12.18 & 13.51 & 81.2 & 22.61 \\
\hline 100 seed weight & 379.11 & 407.76 & 7.87 & 8.16 & 93.0 & 15.63 \\
\hline Oil content & 14.24 & 15.24 & 8.61 & 8.91 & 93.5 & 17.15 \\
\hline Height & 25.17 & 143.95 & 7.62 & 18.22 & 17.5 & 6.56 \\
\hline Collar diameter & 0.03 & 0.11 & 8.22 & 14.93 & 30.3 & 9.33 \\
\hline Volume index & 4742.53 & 19168.55 & 19.91 & 40.02 & 24.7 & 20.40 \\
\hline
\end{tabular}

Of the 72 (36 genotypic and 36 phenotypic) correlations, 13 genotypic and seven phenotypic combinations were significant at $1 \%$ along with four genotypic and one phenotypic combinations was significant at 5\% (Table 5). Skinner et al. (1999) suggested only those correlation coefficients, which are greater than 0.70 or smaller than -0.70 as biologically meaningful so that $50 \%$ of the variation in one trait is predicted by the other. The seed trait pair showing such high correlation was 11 and all were positive. At genotypic level 100 seed weight registered positive significant association with height (0.73) and oil content with volume index (0.71) at $30 \mathrm{MAS}$.

In the present investigation, attempts were made to assess the genetic diversity among the twenty-three CPT's candidate plus trees based on seed and progeny traits using Mahalanobis $\mathrm{D}^{2}$ statistics. On the basis of $\mathrm{D}^{2}$ values for all possible 253 pairs of populations, twenty-three genotypes were grouped into five clusters. Cluster III had maximum number of genotypes which is six and cluster IV and V followed accommodating five genotypes each. Cluster I and II had four and three genotypes respectively (Table 6). The clustering pattern showed that geographical diversity is not necessarily related to genetic diversity. Intra-cluster distance D values ranged between 5.59 in cluster II to 9.56 in cluster V having three and five genotypes respectively (Table 7). Cluster V with 9.56 followed by cluster IV with 9.19 intra-cluster distance were the most diverse because the genotypes used for breeding programme were from different locations. The divergence within the cluster indicates the divergence among the genotypes in the same cluster. Contrarily cluster II showed the minimum intra genetic distance (5.59) between them revealing that these genotypes were somewhat similar in genetic 
constitution and hybridization amongst these groups not showing sufficient variability. Inter-cluster distance ranged from 8.73 between III and V to 14.25 between II and V (Table 7). The highest intercluster distance 14.25 was followed by 13.14 between cluster I and II. Inter-cluster divergence suggests the distance (divergence) between the genotypes of different clusters. The tendency of genotypes from diverse eco-geographic regions to group together in the same cluster or scattered distributions of genotypes of same geographic origin in different clusters have been observed in the present study.

Table 5: Correlation coefficient matrix of seed and progeny growth traits of Madhuca latifolia.

\begin{tabular}{|c|c|c|c|c|c|c|c|c|c|}
\hline Seed traits & & $\begin{array}{l}\text { Seed } \\
\text { breadth }\end{array}$ & $\begin{array}{l}\text { Aspect } \\
\text { ratio }\end{array}$ & $\begin{array}{l}2 \mathrm{D} \\
\text { surface } \\
\text { area }\end{array}$ & $\begin{array}{l}100 \text { seed } \\
\text { weight }\end{array}$ & $\begin{array}{l}\text { Oil } \\
\text { content }\end{array}$ & Height & $\begin{array}{l}\text { Collar } \\
\text { diameter }\end{array}$ & $\begin{array}{l}\text { Volume } \\
\text { index }\end{array}$ \\
\hline \multirow[t]{2}{*}{ Seed length } & G & 0.197 & $0.765^{* *}$ & $0.850^{* *}$ & 0.329 & -0.094 & 0.389 & 0.054 & 0.172 \\
\hline & $\mathrm{P}$ & 0.241 & $0.757^{* *}$ & $0.859^{* *}$ & 0.275 & -0.041 & 0.027 & 0.009 & 0.015 \\
\hline \multirow[t]{2}{*}{ Seed breadth } & G & & $-0.482^{*}$ & $0.673^{* *}$ & 0.148 & 0.034 & 0.351 & 0.600 & $0.550^{* *}$ \\
\hline & $\mathrm{P}$ & & $-0.428^{*}$ & $0.683^{* *}$ & 0.130 & 0.036 & 0.052 & 0.266 & 0.194 \\
\hline \multirow[t]{2}{*}{ Aspect ratio } & G & & & 0.319 & 0.201 & -0.106 & 0.055 & $-0.427^{*}$ & -0.282 \\
\hline & $\mathrm{P}$ & & & 0.342 & 0.159 & -0.064 & -0.041 & -0.205 & -0.156 \\
\hline \multirow[t]{2}{*}{ 2D surface area } & G & & & & 0.323 & -0.085 & $0.469^{*}$ & 0.324 & 0.390 \\
\hline & $\mathrm{P}$ & & & & 0.268 & -0.044 & 0.041 & 0.106 & 0.080 \\
\hline \multirow[t]{2}{*}{100 seed weight } & G & & & & & $0.604^{* *}$ & $0.733^{* *}$ & $0.405^{*}$ & $0.518^{* *}$ \\
\hline & $P$ & & & & & $0.573^{* *}$ & 0.296 & 0.238 & 0.270 \\
\hline \multirow[t]{2}{*}{ Oil content } & G & & & & & & $0.680^{* *}$ & $0.652^{* *}$ & $0.705^{* *}$ \\
\hline & $\mathrm{P}$ & & & & & & 0.273 & 0.328 & 0.330 \\
\hline \multirow[t]{2}{*}{ Height } & G & & & & & & & $0.732^{* *}$ & $0.861^{* *}$ \\
\hline & $\mathrm{P}$ & & & & & & & $0.643^{* *}$ & $0.833^{* *}$ \\
\hline \multirow[t]{2}{*}{ Collar diameter } & G & & & & & & & & $0.978^{* *}$ \\
\hline & $\mathrm{P}$ & & & & & & & & $0.947^{* *}$ \\
\hline
\end{tabular}

*significant at $\mathrm{p}=0.05,{ }^{* *}$ significant at $\mathrm{p}=0.01$

Table 6: Clustering of Madhuca latifolia genotypes using Tocher's method.

\begin{tabular}{lll}
\hline Clusters & $\begin{array}{l}\text { Number of } \\
\text { accessions }\end{array}$ & Accessions (CPTs) \\
\hline I & 4 & CPT-1, CPT-2, CPT-6, CPT-15 \\
II & 3 & CPT-3, CPT-5, CPT-16 \\
III & 6 & CPT-4, CPT-7, CPT-8, CPT-9, CPT-11, CPT-20 \\
IV & 5 & CPT-10, CPT-12, CPT-13, CPT-14, CPT-22 \\
V & 5 & CPT-17, CPT-18, CPT-19, CPT-21, CPT-23 \\
\hline
\end{tabular}


Table 7: Average intra and inter-cluster distance and $\mathrm{D}^{2}$ values."

\begin{tabular}{lrrrrr}
\hline Clusters & I & II & III & IV & V \\
\hline I & $\mathbf{8 . 0 5 6}$ & 13.144 & 9.092 & 11.406 & 10.394 \\
& $\mathbf{( 6 4 . 9 0 6 )}$ & $(172.769)$ & $(82.669)$ & $(130.104)$ & $(108.041)$ \\
II & & $\mathbf{5 . 5 9 1}$ & 12.674 & 10.322 & 14.247 \\
& & $\mathbf{( 3 1 . 2 5 5 )}$ & $(160.618)$ & $(106.540)$ & $(202.974)$ \\
III & & $\mathbf{8 . 7 0 2}$ & 9.739 & 8.725 \\
& & & $\mathbf{( 7 5 . 7 2 5 )}$ & $(94.845)$ & $(76.128)$ \\
IV & & & $\mathbf{9 . 1 9 2}$ & 10.079 \\
& & & & $\mathbf{( 8 4 . 4 9 9 )}$ & $(101.582)$ \\
V & & & & $\mathbf{9 . 5 5 9}$ \\
& & & & & $\mathbf{( 9 1 . 3 6 6 )}$ \\
\hline
\end{tabular}

${ }^{*}$ Figures given in the parenthesis are $\mathrm{D}^{2}$ values.

Table 8: Cluster wise mean values of six seed traits and three progeny traits.

\begin{tabular}{|c|c|c|c|c|c|c|}
\hline Traits\Clusters & $\mathrm{I}$ & II & III & IV & $\mathrm{V}$ & $\begin{array}{r}\text { Percent } \\
\text { contribution } \\
\end{array}$ \\
\hline Seed length $(\mathrm{cm})$ & 35.7 & 35.1 & 33.4 & 31.1 & 30.8 & 5.1 \\
\hline Seed breadth $(\mathrm{cm})$ & 16.9 & 18.1 & 17.5 & 16.9 & 16.8 & 11.1 \\
\hline Aspect Ratio & 2.1 & 1.9 & 1.9 & 1.9 & 1.8 & 0.0 \\
\hline 2D surface area $\left(\mathrm{mm}^{2}\right)$ & 440.1 & 464.0 & 430.3 & 384.0 & 384.6 & 0.0 \\
\hline 100 seed weight $(\mathrm{g})$ & 254.7 & 277.6 & 239.4 & 249.0 & 232.0 & 19.8 \\
\hline Oil content $(\%)$ & 41.3 & 50.2 & 42.2 & 46.0 & 41.8 & 19.4 \\
\hline Plant height $(\mathrm{cm})$ & 63.1 & 75.0 & 64.6 & 65.6 & 64.3 & 4.0 \\
\hline Collar diameter $(\mathrm{cm})$ & 2.1 & 2.5 & 2.3 & 2.2 & 2.2 & 7.1 \\
\hline Volume index $\left(\mathrm{cm}^{3}\right)$ & 297.1 & 461.8 & 346.6 & 341.6 & 319.2 & 33.6 \\
\hline
\end{tabular}

Cluster means indicated a wide range of variation for all the seed and progeny traits (Table 8). The best cluster for seed breadth of $18.1 \mathrm{~mm}, 2 \mathrm{D}$ surface area of $464.0 \mathrm{~mm}^{2}, 100$ seed weight of $277.6 \mathrm{~g}$, oil content of $50.2 \%$, plant height of $75 \mathrm{~cm}$, collar diameter of $2.5 \mathrm{~cm}$ and volume index of $461.8 \mathrm{~cm}^{3}$ was for cluster II. Maximum seed length $(35.7 \mathrm{~mm})$ and aspect ratio $(2.1)$ was recorded by cluster I. Cluster $\mathrm{V}$ recorded minimum for seed length $(30.8 \mathrm{~mm})$, seed breadth $(16.8 \mathrm{~mm})$ and aspect ratio $(1.8)$ and 100 seed weight $(232.0 \mathrm{~g})$ while cluster I recorded minimum for oil content $(41.3 \%)$, plant height $(63.1 \mathrm{~cm})$ collar diameter $(2.1 \mathrm{~cm})$ and volume index $\left(297.1 \mathrm{~cm}^{3}\right)$. Cluster II has genotype (CPT-3, CPT-5 , CPT-16) containing high volume index $\left(578.3 \mathrm{~cm}^{3}\right), 100$ seed weight $(286.3 \mathrm{~g})$, oil content $(51.2 \%)$ and cluster I has genotype (CPT-15) containing high seed length $(39.1 \mathrm{~mm})$ and aspect ratio (2.2). Thus it may be suggested that crosses involving under cluster II and I may result in substantial segregates and further selection for overall improvement of the species.

\section{Discussion}

Seed weight, depends on reserve food material, which is produced as a result of double fertilization (endosperm) and is dominated by the maternal traits and is also influenced by the nutrient availability at the time of seed setting and environmental factors (Allen, 1960; Johnsen et al., 1989). Embryo development and its physiological function are contributed by the maternal as well as by paternal (pollen grain) traits in the species. The occurrence of $M$. latifolia over a wide range of habitats with diverse geo-climatic conditions was expected to be reflected in the genetic constitution of its 
populations. In the present study, the seeds from various CPTs exhibited significant seed trait variability (Table 3 ) which could be attributed to population isolations that inturn influence gene flow. Significant variability of seed characters like; seed size and weight was observed in seeds of the selected plus trees (Bagchi and Sharma, 1989) and among various provenances of Santalum album (Veerendra et al., 1999). Genetic control of seed size traits has been observed in several tree species (Loha et al., 2006).

Though the selection of superior trees was carried out intensively and clonal superiority over seed raised plants was established (Kumar, 1995), genetic superiority per se needs to be determined. Genetic estimates could considerd as useful tools in predicting the amount of gain expected in short period of time. The variation among genotypes is commonly used as an estimate of total genetic variation and to calculate the degree of genetic control for a particular trait (Foster and Shaw, 1988). Marginal difference between PCV and GCV and high estimates of heritability for all pod and seed traits studied revealed the presence of heritable nature in variability (Table 4). The magnitude of the error variance was relatively lower than the genotypic variance for all traits except for height, collar diameter and volume index (data not given). Higher magnitude of genotypic variance over error variance on one hand and close values of phenotypic and genotypic variances on the other hand for all the seed traits, indicated considerable scope for selection. Relatively high value of genotypic variance that resulted in high estimates of heritability which contributed to the high genetic gains expected in oil content. Gains from tree breeding programs depend on the type and extent of genetic variability. In the present study the genotypic coefficient of variation and the genetic gain were found to be comparatively higher for an important trait such as volume index, 100-seed weight and oil content. The high estimates of heritability combined with high genetic advance suggests that population means for volume index may be changed considerably by selecting the superior $5 \%$ of the genotypes. High heritability for growth parameters have been reported in Tectona grandis (Gera et al., 2001) and accompanied by high genetic advance in Prosopis cineraria (Solanki et al., 1984).

As variation among genotypes is used for estimation of genetic variation and genetic gain, covariance estimates between traits can be used to estimate genetic correlations between the traits (Foster, 1986). In genetic improvement of $M$. latifolia clear understanding of the relationships among different seed and progeny traits is very essential. Correlation establishes the extent and cause of association between seed traits and its attributes so that these components may form additional criteria for selection in breeding program. Correlated quantitative traits are of a major interest in an improvement program, as the improvement of one character may cause simultaneous changes in the other character. Similar correlation trend was seen in Jatropha curcas (Kaushik et al., 2007a) and Pongamia pinnata (Kaushik et al., 2007b) seed traits. Hence 100 seed weight may be included among the criteria for selection of plus trees. The genotypic correlation is an estimated value, whereas, phenotypic correlation is a derived value from the genotype and environmental interaction (Chaturvedi and Pandey 2004). The genotypic correlation is, therefore, a more reliable estimate for examining the degree of relationship between character pairs. The present study indicates the correlation of 100 seed weight and oil content to growth of M. latifolia at juvenile stage. Positive correlation between seed weight and seedling height in Pinus spp. has been observed but it disappeared with the growing age of the seedlings (Righter, 1945). However correlation between seed weight and height till 15 years was observed in Pinus taeda (Robinson and Van Buijtenen, 1979). Khalil (1981) stated that, significant positive correlation and regression between 1,000 seed weight and height at four years in Picea glauca which is not mere carryover of the initial effect in the first year growth but appears to be genetically correlated and recommended that seed weight may be included among the criteria for selection of plus trees. 
Genetic diversity in plant species is a gift to mankind as it forms the basis for selection and further improvement. In Jatropha curcas Kaushik et al. (2007a) attempted to analyse the diversity among the 24 CPT's from Haryana of India. In the present study clustering pattern showed that geographical diversity is not necessarily related to genetic diversity (Table 6). In rice it is reported that this kind of genetic diversity might be due to differential adoption, selection criteria, selection pressure and environment (Vivekananda and Subramanian, 1993). This indicated that genetic drift produces greater diversity than the geographic diversity (Singh et al., 1996). Absence of any relationship between genetic diversity and geographical distribution is in accordance with the findings of Kaushik et al. (2007a) and Gohil and Pandya, (2008) in J. curcas. The contribution of individual characters to the diversity has been studied. The trait volume index contributed maximum for $33.6 \%$ for genetic diversity and rank total of 85 . The character contributing maximum diversity can be given more emphasis for the purpose of fixing priority of parents in hybridization program. Cluster $\mathrm{V}$ and cluster IV with high intra-cluster distance were the most diverse and the divergence within the cluster indicates the divergence among the genotypes in the same cluster (Table 7). Hence, best suited for within group is the hybridisation. Cluster means indicated crosses involving under cluster II and V and cluster II and I may result in substantial segregates and further selection for overall improvement of species. In general, the cluster II and I, V exhibited high and low mean values respectively for most of the characters (Table 8). It is also suggested that for creating variability and developing the best selection a large number of divergent lines, instead of few should be used in the hybridization. Earlier studies, in crop plant had indicated that inter-mating of divergent groups would lead to greater opportunity for crossing over which would release latent variation by breaking up predominantly repulsion linkage (Thoday, 1960) and utilization of diverse parents in breeding was also stressed by (Singh et al., 1981).

\section{Conclusions}

CPT-3, CPT-5 and CPT-16 found to be superior for volume index, 100 seed weight and oil content respectively; hence seeds of these CPT may be given importance for massive afforestation programme. The traits 100 seed weight and oil content were highly correlated with growth (volume index) of the tree. In addition, seed breadth expressed correlation with volume index. Hence identification of good CPTs may be graded based on seed weight and/or size and/or shape is advantageous. Since traits viz. 100 seed weight and oil content are under strong genetic control, improvement in these characters can bring improvement in volume index. The divergence among the genotypes in cluster $\mathrm{V}$ and cluster IV as indicated by intra-cluster distance can be best used for within group hybridization. Inter-cluster distance suggested that crosses involving under cluster II \& V and cluster II and I may result in substantial segregates and further selection for overall improvement of the species.

As tree improvement is a continuous programme, progenies of all CPTs will further be evaluated for total yield and oil content in future to check the pattern of character association and selection of elite material. The present study can however serve as a pointer to be compared with the results to be obtained at later stages especially seed and oil yield and also to establish the correlations. This study would perspectively determine whether genetic analysis at early stage is reliable. If reliable, genetic assessment for other population can also be carried out with suitable correlation factors the extent of relationship can be determined

\section{Acknowledgements}

The author is grateful to National Bank for Agriculture and Rural Development (NABARD), Mumbai for financial assistance in the form of Research and Development grants and The Director, 
Institute of Forest Productivity (ICFRE), Ranchi for providing the necessary facilities. Sincere thanks are due to CCF (Research) and field staff of Jharkhand forest department for their cooperation in survey and identification and collection of clones.

\section{Reference}

Allard, R.W. 1999. Principles of Plant Breeding, (2 ${ }^{\text {nd }}$ edition) John Wiley \& Sons, NY, pp.254.

Allen, G.S. 1960. Factors affecting the viability and germination behaviour of coniferous seed. IV. Stratification period and incubation temperature, Pseudostuga menziesii (Mirb.) Franco. Forestry Chronicle, 36: 18-19.

Bagchi, S.K. and Sharma, V.P. 1989. Biometrical studies on seed characters of Santalum album L. Silvae Genet, 38: 152-153.

Burton, G.W. 1952. Quantitative inheritance of grass. Proceedings of $6^{\text {th }}$ International Grassland Congress held at Pennsylvania State College. Pa. U.S., 1: 74-83.

Chaturvedi, O.P. and Pandey, N. 2004. Correlation and path analysis studies between biomass and other characters in Bombax ceiba L. Silvae Genetica, 53: 5-6.

CSIR. 1998. Wealth of India: A dictionary of Indian raw material and industrial products. Vol. VI (LM) Council of Scientific and Industrial products, New Delhi, pp. 207-216.

Foster, G.S. 1986. Provenance variation of eastern cottonwood in the lower Mississippi valley. Silvae Genet, 35: 32-38.

Foster, G.S. and Shaw, D.V. 1988. Using clonal replicates to explore genetic variation in a perennial plant species. Theor. Appl. Genet, 76: 788-794.

Gera, M., Gera, N. and Sharma, S. 2001. Estimation of variability in growth characters of forty clones of Tectona grandis. Indian Forester, 127: 639-43.

Gohil, R.H. and Pandya, J.B. 2008. Genetic diversity assessment in physic nut (Jatropha curcas L.) International Journal of Plant Production, 2(4): 321-326.

Gomez, A.K. and Gomez, A.A. 1984. Statistical procedure for agricultural research. John Wiley and sons, Inc.

Goulden, C.H. 1952. Some distance properties of latent root and vector methods used in multivariate analysis. Biometrica, 53: 325-338.

Hill, J., Nelson, E. and Tilman, D. 2006. Environmental, economic and energetic costs and benefits of biodiesel and ethanol biofuels. Proceedings of National Academic of Science, USA, 103: 11206-11210.

Johanson, H.W., Robinson, H.F. and Comstock, R.E. 1955. Estimate of genetic and environmental variability in soyabeans. Agron. J, 47: 314-318.

Johnsen, O., Dietrichson, J. and Skaret, G. 1989. Phenotypic changes in progenies of northern clones of Picea abies (L.) Karst. grown in a southern seed orchard. III. Climate changes and growth in a progeny trial. Scand. J. For. Res, 4: 343-350.

Kaushik, N., Kumar, K., Kumar, S., Kaushik, N. and Roy, S. 2007a. Genetic variability and divergence studies in seed traits and oil content of Jatropha (Jatropha curcas L.) accessions. Biomass Bioenergy, 31: 497-502.

Kaushik, N., Kumar, S., Kumar, K., Beniwal, R. S., Kaushik, N. and Roy, S. 2007b. Genetic variability and association studies in pod and seed traits of Pongamia pinnata (L.) Pierre in Haryana, India. Genet Resour Crop Evol, 54: 1827-1832.

Khalil, M.A.K. 1981. Correlation of Juvenile height growth with cone morphology and seed weight in white spruce. Silvae Genetica, 30(6): 179-181. 
Kumar, A. 1995. Genetic improvement of Casuarina equisetifolia. PhD thesis, Forest Research Institute (Deemed University), Dehra Dun, India.

Loha, A., Tigabu, M., Teketay, D., Lundkvist, K. and Fries, A. 2006. Provenance variation in seed morphometric traits, germination and seedling growth of Cordia africana Lam. New Forests, 32: 71-86.

Mahadevan, N.P., Sivakumar, V. and Gurudev Singh, B. 1999. Relationship of cone and seed traits on progeny growth performance in Casuarina equisetifolia Forst. \& Forst. Silvae. Genet, 48(6): 273-277.

Mahalonobis, P.C. 1936. On the generalized distance in statistics. Proceeding of National Institute of Sciences, India, 2: 49-55.

Manavalan, A. 1990. Seedlind vigour and bioproductivity in woody biomass Species. Ph.D. Thesis, Madurai Kamaraj University, Madurai, India.

Rao, C.R. 1952. Advanced statistical methods in biomatrics research. John Wiley and Sons, Inc., NewYork, 260pp.

Righter, F.I. 1945. Pinus: the relationship of seed size and seedling size to inherent vigor. Journal of Forestry, 43: 131-137.

Robinson, J.F. and Van Buijtenen, J.P. 1979. Correlation of seed weight and nursery bed traits with 5, 10 and 15 year volume in loblolly pine progeny test. Forest Science, 35(4): 591-596.

Singh, A.K., Singh, S.B. and Singh, S.M. 1996. Genetic divergence in scented and fine genotypes of rice (Oryza sativa L.) Ann Agric Res, 17: 163-166.

Singh, R.K. and Chaudhary, B.D. 1977. Biometrical methods in quantitative genetic Analysis. Kalyani Publication, New Delhi, pp.596.

Singh, Y.P., Kumar, A. and Chauhan, B.P.S. 1981. Genetic divergence in pearl millet. Indian Journal of genetics, 41: 186-190.

Skinner, D.Z., Bauchan, G.R., Auricht, G. and Hughes, S. 1999. A method for the efficient management and utilization of large germplasm collections. Crop Science, 39: 1237-1242.

Solanki, K.R., Muthana, K.D., Jindal, S.K. and Arora, G.D. 1984. Variability, heritability and correlation for growth parameters in Prosopis cineraria. Journal of Tree Science, 3: 86-8.

Thoday, J.M. 1960. Effect of disruptive selection. III. Coupling and repulsion. Heredity, 14: 35-49.

Veerendra, H.C.S., Ramalakshmi, S. and Mallesha, B.B. 1999. Variation in seed characterstics in provenances of sandal (Santalum album L.). Indian Forester, 125: 308-312.

Vivekananda, P. and Subramaninan, S. 1993. Genetic divergence in rainfed rice. Oryza, 39: 60-62. 